\title{
New technique for angiographic visualization of membraneous subaortic stenosis
}

\author{
Abraham I. Schaffer, Herbert Kania, Cesare E. Cucci, and Nicholas P. DePasquale \\ From the Departments of Medicine and Pediatrics, \\ Lenox Hill Hospital, New York City, U.S.A.
}

A new technique is described for visualizing the subvalvular chamber of discrete membraneous subaortic stenosis. A Lehman ventriculography catheter is positioned so that its side holes lie within the chamber while its tip passes through the stenotic orifice into the body of the ventricle. $A$ small amount of contrast injected directly into the subvalvular chamber outlines the membrane clearly. During diastole the contrast refluxes into the body of the ventricle, thus outlining the site and size of the stenotic orifice. Four patients were studied successfully.

The most common type of fixed subaortic stenosis is the membraneous type. A fibrous membrane extends across the outflow tract I-20 $\mathrm{mm}$ below the aortic ring. It is attached to the septum and anterior leaflet of the mitral valve and forms the floor of a subaortic chamber (Reis et al., I97I).

A reliable diagnosis can be made only by cardiac catheterization. Indications for operation and the type of operation depend not only on the size of the pressure gradient but also on the anatomy of the stenosis. The latter is usually shown by an injection of a large bolus of contrast material into the body of the left ventricle (Baltaxe, Moller, and Amplatz, 1970; Baron, 197I). The membrane shows as a thin translucent line below the aortic valve ring. However, visualization of the membrane is of variable quality and few details of the anatomy of the subvalvular chamber are obtained.

This report describes a method for showing the anatomy by injecting small amounts of contrast directly into the subaortic chamber.

\section{Technique}

The Lehman ventriculography catheter (U.S. Catheter Corp. Cat. No. 5470) appears most suitable in our experience. It has several side holes several $\mathrm{cm}$ behind a thin solid tip. Because the side holes are not in a single plane, it is not the best catheter for determining the anatomical level of the pressure gradient. However, it permits a careful positioning of the side holes within the subvalvular chamber with little risk of losing an often hard-gained entry into the left ventricle.

Received 4 October 197I.
If the subaortic chamber is shallow, the side holes are positioned to straddle the aortic valve.

Contrast, I to ro $\mathrm{ml}$, is injected by hand or machine. In the most recent case we used the Contrac injector (Siemens) which permitted the injection to be confined to diastole (Schad et al.,

FIG. I Patient I. Frame from cineangiogram (left anterior oblique view; diastole) shows membranous subaortic stenosis and ventricular septal defect. The aortic catheter has passed through the defect into the right ventricle $(R V)$. Side holes lie in the subvalvular chamber (SVC) which is bounded by aortic leaflets $(A V)$ above, membrane below, and the mitral valve (MV) and septum (MS) on the sides. MS is flaccid, protruding out during systole and collapsing in diastole and could be made up of the membranous septum and/or tricuspid valve adherent to edges of septal defect. Reflux of contrast outlines the stenotic orifice and the small septal defect. $L V=l e f t$ ventricle.
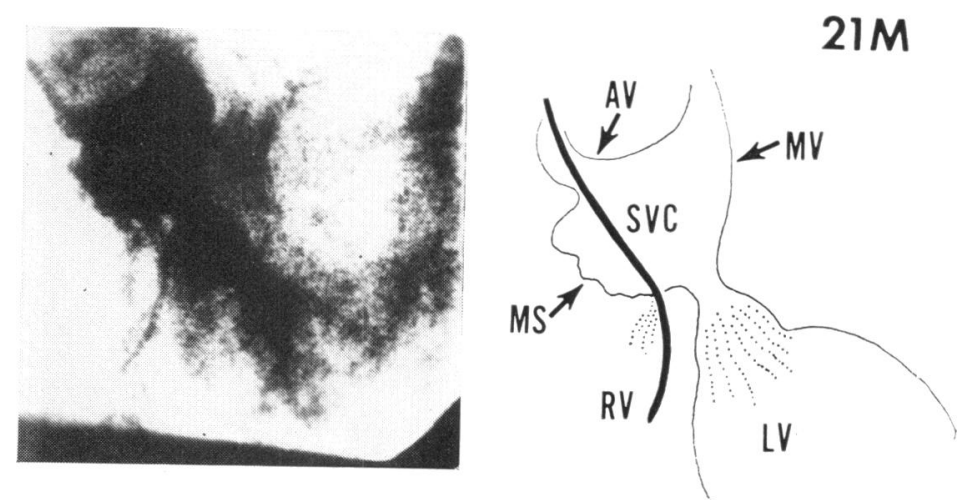
1968). Extrasystoles induced by the injection are infrequent with this pathology. This enhances the efficiency of the phased injection and reduces even further the amount of contrast needed. The absence of arrhythmias and small volume of contrast permits repeated injections. Cine recordings were made, usually in the left anterior oblique view.

The subvalvular chamber is outlined clearly. The aortic valve forms the roof and the membrane forms the floor; the side walls are made up of the septum and the aortic leaflet of the mitral valve. During diastole the contrast refluxes through the stenotic orifice of the membrane into the body of the ventricle, often as a distinct jet which reveals the site and size of the stenosis.

\section{Results}

Four patients with discrete membranous subaortic stenosis have been studied by this technique. Details are given in the Table and Fig. I and 2. In each case the chamber, membrane, and stenotic orifice could be clearly identified. One extrasystole was induced in one case and in none of the others.

\section{Discussion}

Because many patients with membranous subaortic stenosis have associated aortic insufficiency, a selective injection of contrast material into the aortic root has been used to visualize the subvalvular chamber (Edwards et al., I965; H. Newfeld, I970, personal communication). An aortic root injection was made in all our patients. None had aortic insufficiency. Therefore, the subaortic chamber failed to be visualized in each case.

The freedom from extrasystoles induced by the injection is worth noting. Perhaps the myocardium within the subvalvular chamber has little or no specific conduction tissue. In contrast to working myocardium, the specific tissue is thought to be the most common source of ventricular ectopic beats. Another possible explanation is that the catheter is prevented from touching the myocardium by its tip being constrained within the stenotic orifice of the membrane. When membranous subaortic stenosis is not present, an injection into the outflow tract of the left ventricle usually induces considerable ectopic activity.

\section{References}

Baltaxe, H. A., Moller, J. H., and Amplatz, K. (1970). Membraneous subaortic stenosis and its associated malformations. Radiology, 95, 287.

Baron, M. G. (197I). The angiocardiographic diagnosis of valvular stenosis. Circulation, 44, I43.

Edwards, J. E., Carey, L. S., Neufeld, H. N., and Lester, R. G. (1965). Congenital Heart Disease, p. 724. Saunders, Philadelphia.

Reis, R. L., Peterson, L. M., Mason, D. T., Simon, A. L., and Morrow, A. G. (1971). Congenital fixed

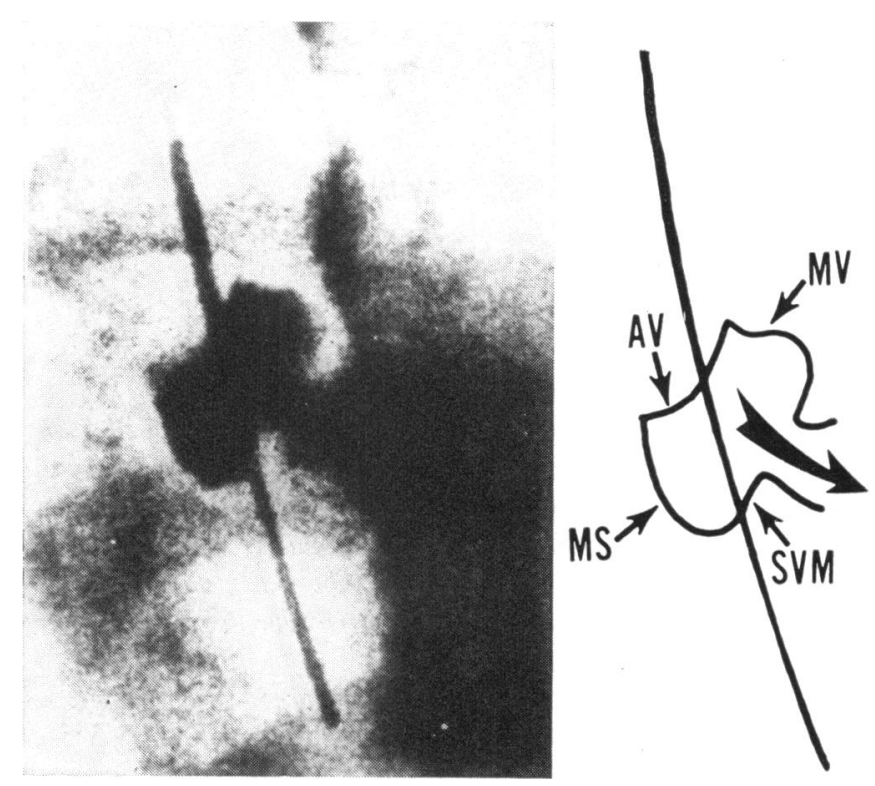

FIG. 2 Patient 4. Frame from cineangiogram (left anterior oblique; diastole). Injection confined to diastole. Abbreviations as in Fig. $I$. $S V M=$ subvalvular membrane. The catheter has passed through the edge of the stenotic orifice in the membrane. The refluxing contrast material and the catheter tip are both in the $L V$ though they appear to be in separate chambers in the drawing. The subaortic chamber and its stenotic orifice are clearly outlined.

TABLE Selected data in 4 patients with discrete membranous subaortic stenosis

\begin{tabular}{|c|c|c|c|c|c|}
\hline $\begin{array}{l}\text { Patient } \\
\text { No. }\end{array}$ & $\begin{array}{l}\text { Age } \\
(y r)\end{array}$ & $\operatorname{Sex}$ & $\begin{array}{l}\text { Peak systolic } \\
\text { pressure gradient } \\
(\mathrm{mmHg})^{\star}\end{array}$ & $\begin{array}{l}\text { Depth of } \\
\text { subvalvular } \\
\text { chamber }(\mathrm{mm}) \dagger\end{array}$ & Remarks \\
\hline $\mathbf{I}$ & $2 \mathbf{I}$ & $\mathbf{M}$ & 50 & 20 & $\begin{array}{l}\text { Ventricular septal } \\
\text { defect; pulmonary } \\
\text { valve stenosis }\end{array}$ \\
\hline 2 & 8 & $\mathbf{M}$ & 45 & IO & Confirmed at operation \\
\hline 3 & 6 & $\mathbf{F}$ & 65 & 15 & Confirmed at operation \\
\hline 4 & 15 & $\mathbf{F}$ & 20 & 18 & \\
\hline
\end{tabular}

* Pressure gradient between body of left ventricle and subvalvular chamber. † Estimated from angiogram.

subvalvular aortic stenosis. Circulation, 43, Suppl. I, p. II.

Schad, N., Stucky, J. P., Brunner, H., and Schad, H. (1968). The intermittent phased injection of contrast material into the heart. American fournal of Roentgenology, Radium Therapy, and Nuclear Medicine, 104, 464 .

Requests for reprints to Dr. Abraham I. Schaffer, I80 East 64th Street, New York, N.Y. I002I, U.S.A. 